\section{Prof. S. G. M. Ure}

Prof. S. G. M. URE, whose death at the age of sixty occurred on December 25, was widely known as one of the pioneers of chemical engineering education in Great Britain. Born in 1881, he attended Allen Glen's School and later graduated at the University of Glasgow, where he took the degrees of B.Sc. in engineering and M.A. in mathematics and physics. On leaving the university he spent five years in the shipbuilding industry before taking up the educational work to which, with one short interval, the remainder of his career was devoted.

To those who were actively concerned with the vast production programme of the War of 1914-18 the difficulties which arose through the lack of trained scientific personnel made an abiding impression. They determined that, with the return of settled conditions, a concerted effort should be made to introduce into our universities a form of training which would produce men having the qualifications necessary to ensure the development of chemical industry on sound progressive lines. The names of Lord Moulton, Sir Arthur Duckham and Prof. Hinchley will long be remembered in this connexion; and, first as assistant to Hinchley, later as his successor, Prof. Ure took a notable part in the crusade.

In 1921 Ure was appointed lecturer in chemical engineering at the Imperial College of Science and Technology and in the following year he became a founder-member of the Institution of Chemical Engineers. From then until his death his energies were devoted unsparingly to the cause of chemical engineering training and to the service of the new Institution.

In 1932 he succeeded Hinchley as assistant professor of chemical engineering in the Imperial College, and in 1937 he was closely associated with the framing of an undergraduate course in the subject.

Ure was associated with many scientific activities. $\mathrm{He}$ was first elected to the Council of the Institution of Chemical Engineers in 1928 and became a vicepresident in 1937; he served on numerous committees of the Institution and for ten years was editor of its Transartions.

D. M. NEwitT.

\section{Dr. J. S. Owens}

THE death of Dr. J. S. Owens on December 6 removes a most useful and public-spirited man of science. For nearly thirty years Dr. Owens has been the moving spirit in the investigation of atmospheric pollution on its quantitative side. He devised the instruments in use, and co-ordinated, tabulated and prepared for publication all the data on which the progressive changes in the amount of pollution in the atmosphere are evaluated.

Owens was born at Enniscorthy, Co. Wexford, Ireland, on July 28, 1871. He took the M.D. degree at Trinity College, Dublin, in 1896, but soon gave up medicine for engineering. He was a successful civil engineer chiefly in connexion with sea defence works and mining, and became consulting engineer to the San Domingo Mines in Portugal, and the Rio Tinto Copper Mines in Spain.

As the result of the Smoke Abatement Exhibition in 1912 a committee was formed for the systematic investigation of atmospheric pollution, and Owens became its secretary. In 1917 the work of this committeo was transferred to the Meteorological Office and Owens was appointed part-time superintendent in charge of the Atmospheric Pollution Division. In 1927 the Department of Scientific and Industrial Research took over the investigation of atmospheric pollution from the Meteorological Office, and in order that the supervision of the instruments and the compilation of statistics should remain in his charge, Owens was appointed superintendent of observations.

For the quantitative investigation of atmospheric pollution Owens devised three main instruments and several instruments of lesser importance. The most widely used of these instruments was the standard deposit gauge. This consisted of a simple collecting basin having an opening of approximately four square feet exposed in the open on a stand at a height of four feet. All the pollution and rain which fell into the basin was collected and analysed, giving valuable information as to the amount and nature of the pollution deposited from the atmosphere. The second instrument was the automatic filter gauge for determining the amount of pollution contained in a given volume of air, and the third the jet dustcounter, for counting the number of particles of soot and other insoluble particles contained in the air. All three instruments have performed invaluable service, 123 deposite gauges and 16 automatic filters being maintained by municipalities and other public bodies in 1938 .

Owens's inventive skill, conscientious compilation of records and personal enthusiasm have resulted in Great Britain being far ahead of any other country in knowledge of the pollution of its atmosphere-in this he has performed a valuable public servico. Three days before his death Owens was awarded the Symons Gold Medal by the Royal Meteorological Society "for distinguished work done in connexion with Meteorological Science".

\section{Mr. R. S. Herries}

Robert Stansfield HerRIes died in December last at the age of eighty-one years. $\mathrm{He}$ took an active part in the work of the Geological Society, of which he was secretary from 1897 until 1905 and treasurer from 1921 until 1929 ; and of the Palæontographical Society, of which he was treasurer from 1914 until 1938. He was president of the Geologists' Association during 1906-8, and contributed the section on East Yorkshire to "Geology in the Field" published by the Association. Herries collaborated with the late H. W. Monckton in research on the Bagshot Beds of the London Basin. His geological collection (including the one made by his brother, the late Sir W. H. Herries) was presented to the Sedgwick Museum, Cambridge, with the exception of fossils from the Yorkshire coast, which he gave to the Yorkshire Museum, York.

WE regret to announce the following deaths :

The Right Hon. the Earl of Berkeley, F.R.S., on January 15, aged seventy-six.

Dr. C. D citizenship in the University of Glasgow, on January 22 , aged sixty-two.

Prof. R. S. Seton, emeritus professor of agriculture in the University of Leeds, on January 12, aged seventy-four. 